\title{
Mao-to Prolongs the Survival of and Reduces TNF- $\alpha$ Expression in Mice with Viral Myocarditis
}

\author{
Zhu Shijie', Junji Moriya', Jun'ichi Yamakawa', Rui Chen', Takashi Takahashi', \\ Hiroyuki Sumino ${ }^{2}$, Takeshi Nakahashi ${ }^{3}$, Kunimitsu Iwai $^{3}$, Shigeto Morimoto ${ }^{3}$, \\ Nobuo Yamaguchi ${ }^{4}$ and Tsugiyasu Kanda ${ }^{1}$
}

${ }^{1}$ Department of General Medicine, Kanazawa Medical University, 1-1 Daigaku, Uchinada-machi, Kahoku-gun, Ishikawa 920-0293, ${ }^{2}$ Department of Medicine and Biological Science, Gunma University Graduate School of Medicine, 3-39-22 Showa-machi, Maebashi, Gunma 371-8511, ${ }^{3}$ Department of Geriatric Medicine and ${ }^{4}$ Fundamental Research for Complementary and Alternative Medicine, Kanazawa Medical University, 1-1 Daigaku, Uchinada-machi, Kahoku-gun, Ishikawa 920-0293, Japan

Goal of this study was to evaluate effects of Mao-to on development of myocarditis induced by encephalomyocarditis (EMC) virus in mice. Mice were randomly divided into five groups. Group $\mathrm{N}$ included uninfected controls $(n=18)$, while group A, B and C underwent intraperitoneal injection of EMC virus. Group A was administered oral saline from day 0 to day 4. Group B was administered oral Mao-to $\left(500 \mathrm{mg}^{-1} \mathrm{~kg}^{-1}\right.$ day $\left.{ }^{-1}\right)$ from day 0 to day 4. Group $\mathrm{C}$ was administered Mao-to from day 2 to day 6. Group D was administered Mao-to from day 5 to day 10. Treated mice were followed for survival rates during 2 weeks after infection. Body weight (BW) and organ weights including heart (HW), lungs, thymus and spleen were examined on days 4, 6 and 14. Survival rate of group C (36.4\%) was significantly improved compared with group A, B or D $(0 \%$ of each, $P<0.05)$. HW and $\mathrm{HW} / \mathrm{BW}$ ratio in group $\mathrm{C}$ was significantly $(P<0.05)$ lower than those in group $\mathrm{A}, \mathrm{B}$ or $\mathrm{D}$. Viral titers of hearts were significantly different among groups $\mathrm{A}, \mathrm{B}$ and $\mathrm{C}$. Cardiac expression in tumor necrosis factor- $\alpha(\mathrm{TNF}-\alpha)$ was significantly reduced in group $\mathrm{C}$ in comparison with group $\mathrm{A}, \mathrm{B}$ or D on day 6 by immunohistochemical study. Administration of Mao-to starting on day 2 improves mortality resulting from viral myocarditis in mice with reduced expression of cardiac TNF- $\alpha$. These findings suggest that timing of Mao-to is crucial for preventing cardiac damage in mice with viral myocarditis.

Keywords: Mao-to-viral myocarditis - tumor necrosis factor- $\alpha$

\section{Introduction}

Myocarditis is an important cause of cardiomyopathy in young patients (1). Therapeutics for myocarditis have been restricted to supportive care including basic medications (2). Randomized trials of immunosuppressive

For reprints and all correspondence: Tsugiyasu Kanda, MD, Department of General Medicine, Kanazawa Medical University, 1-1 Daigaku, Uchinada-machi, Kahoku-gun, Ishikawa, 920-0293, Japan. Tel: +81-76-286-2211 (ext. 3841); Fax: +81-76-286-2702; E-mail: kandat@kanazawa-med.ac.jp agents have failed to show a benefit (3). Immunomodulative agents have been tried with limited effects (4). In severe cases, heart transplantation presents the only therapeutic option (1). Anti-inflammatory and anti-viral agents are needed to improve outcomes in these patients. Mao-to (Ma-Huang-tang in Chinese) is traditionally used in Japan and China for treatment of influenza-like illness (high fever, headache, pain and cough) since ancient times. Component herb names (botanical names) of Mao-to are as follows: Ephedra Herba (stem of Ephedra Sinica Stapf), Cinnamomi Cortex (bark of 
Cinnamomum cassia Blume), Armenicae Semen (semen of Prunus Armeniacae Linne) and Glycyrrhizae Radix (root of Glycyrrhizae uralensis Fisher) (5). Ephedra Herba was reported to show the in vitro anti-influenza viral effects and augments the production of inflammatory cytokines including interleukin-6 and interleukin-1 (6,7). Moreover, Cinnamomi Cortex, which contains Mao-to, suppress IL- $1 \alpha$ production in the influenza virus-infected mice (8). Moreover, Mao-to has been studied for its anti-viral and anti-autoimmune effects $(9,10)$. Recently, antipyrulent effect of Mao-to was reported in patients with influenza infection (6). However, the effects of Mao-to in viral myocarditis have not been studied. Inflammatory cytokines are involved in the pathogenesis of myocardial injury in viral myocarditis.

Tumor necrosis factor- $\alpha(\mathrm{TNF}-\alpha)$ is a proinflammatory cytokine (11) that plays a crucial role in the initiation and continuation of inflammation and immunity (12). This cytokine has been implicated in the pathogenesis of cardiovascular diseases, especially in viral myocarditis. Our previous work showed that cardiac expression of TNF- $\alpha$ mRNA is increased in a mouse model of viral myocarditis (13). Over production of TNF- $\alpha$ is generally considered to be harmful to the cardiovascular system, because systemic administration of $\mathrm{TNF}-\alpha$ results in myocardial depression (14) and cardiomyopathy (15). Cardiac-specific over-expression of TNF- $\alpha$ has been reported to cause severe myocarditis in mice $(16,17)$.

Therefore, we hypothesized that Mao-to would modify viral myocarditis through anti-viral and anti-inflammatory effects and that cardiac expression of TNF- $\alpha$ was studied as an indicator of myocardial damages.

\section{Methods}

\section{Mice}

Eight-week-old C3H female mice (Charles River, Japan) were used in the experiments.

\section{Virus}

A myocarditic variant of encephalomyocarditis (EMC) virus was obtained from Y. Seto, Keio University, Tokyo, Japan. Encephalomyocarditis virus was cultured and purified followed by previous report (18). Animals were inoculated intraperitoneally with 500 plaqueforming units of EMC virus in $0.1 \mathrm{ml}$ of saline.

\section{Chemicals}

Mao-to which was supplied by Tsumura Co. (Tokyo, Japan) was dissolved in distilled water, and diluted with distilled water to the appropriate concentration. HPLC finger print pattern of Mao-to is shown in Fig. 1.
Mao-to solution at the dose of $500 \mathrm{mg}^{-1} \mathrm{~kg}^{-1}$ was administered orally once daily to the mice. The dose of Mao-to was based on the findings in previous reports $(19,20)$. The control mice were given saline.

\section{Treatment Protocol}

A total of 135 mice were assigned randomly to five groups. Mice in groups $\mathrm{B}$ and $\mathrm{C}$ received Mao-to $10 \mathrm{mg}$ per mouse in $0.1 \mathrm{ml}$ saline $\left(500 \mathrm{mg}^{-1} \mathrm{~kg}^{-1} \mathrm{day}^{-1}\right)$ once daily for 5 days. Group A was administered with $0.1 \mathrm{ml}$ saline from day 0 to day 4 . Group B was administered with $0.1 \mathrm{ml}$ Mao-to from day 0 to day 4 . Group $\mathrm{C}$ was administered with $0.1 \mathrm{ml}$ Mao-to from day 2 to day 6 . Group D was administered $0.1 \mathrm{ml}$ Mao-to from day 5 to day 10. Group $\mathrm{N}$ was the uninfected control group. The survival rate of each group was monitored during the observation period. Body weight and organ weight, and histopathologic changes in the heart were examined on day 4,6 and 14 after infection.

\section{Pathologic Examination}

The heart and other organs were weighed. Body weight (BW) also was recorded. One half of each organ was fixed in $10 \%$ buffered formalin and stained with hematoxylin-eosin; the other half was frozen in embedding compound at $-120^{\circ} \mathrm{C}$ for immunohistochemical studies. Transverse sections of ventricular myocardium were graded for severity of necrosis and mononuclear cell infiltration on a scale from 1 to 4 as follows: grade 1, lesions involving $<25 \%$ of the ventricular myocardium; grade 2, lesions involving $25-50 \%$ of the myocardium; grade 3 , lesions involving $50-75 \%$ of the myocardium and grade 4 , lesions involving $75-100 \%$ of the myocardium. Tissues were evaluated blindly by an experienced pathologist who was familiar with grading murine viral myocarditis and had no knowledge of the study design.

\section{Measurements of Myofiber Diameter}

In the lateral wall of the left ventricle, myocardial fiber diameter was determined by measuring the shortest diameter at the level of the nucleus of 50 myocardial fibers from each group with an ocular micrometer in the stained cross-sectional areas.

\section{Immunohistochemical Examination}

To visualize the presence and anatomic localization of TNF- $\alpha$ within the myocardium, immunohistochemical studies were performed using an avidin biotin complex method (Vectastain ABC kit, Vector Laboratories, Burlingame, CA) as previously described (21). To minimize the background staining, all sections were first blocked with normal goat serum for $20 \mathrm{~min}$ at room temperature. 


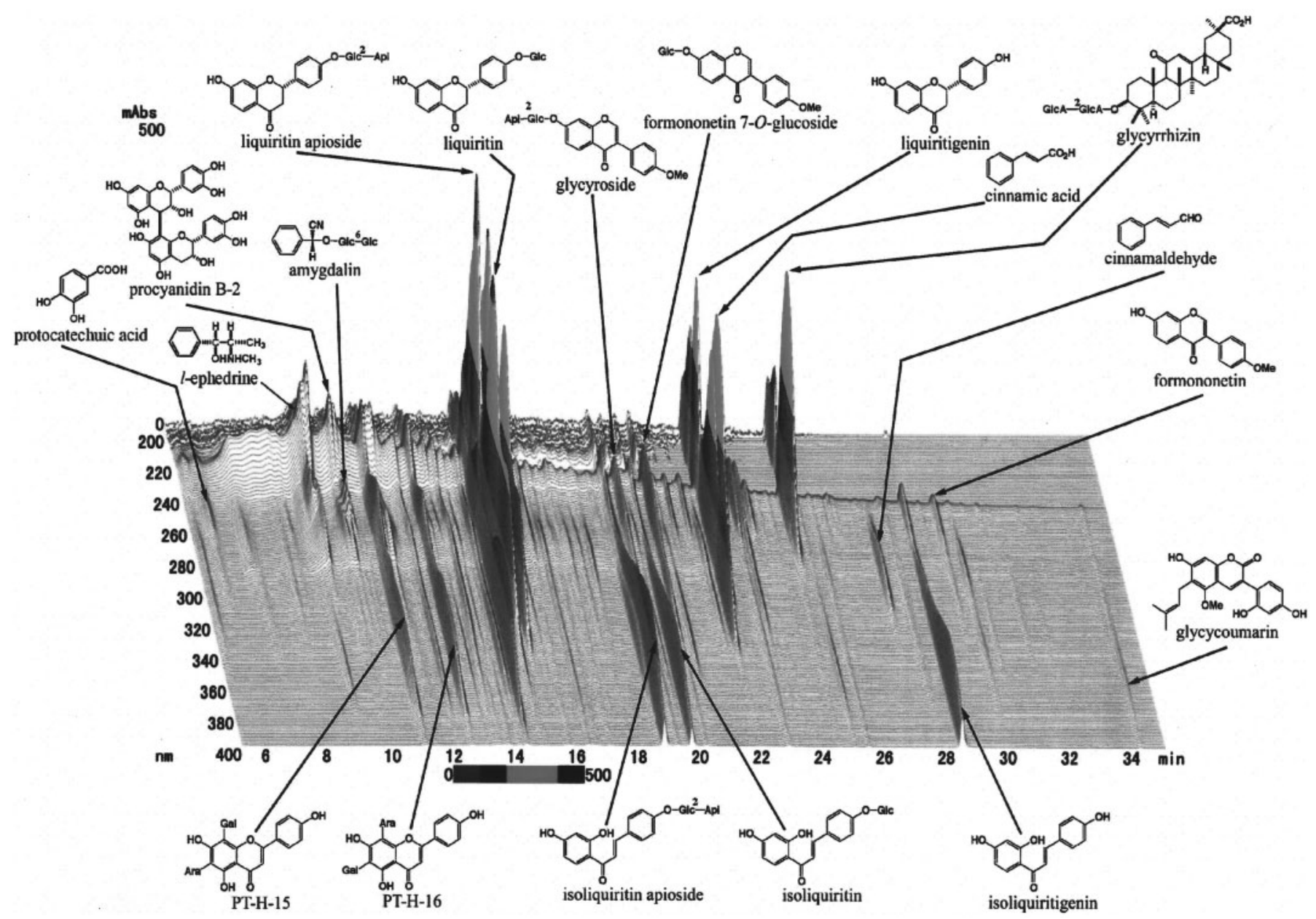

Figure 1. HPLC finger print pattern of Mao-to. HPLC conditions: Pulp: LC-10AD vp (Shimadzu, Japan); column: TSK-GEL ODS-80TS column $(250 \times 4.6 \mathrm{~mm}$; Tosoh, Japan); mobile phase: $0.05 \mathrm{~m} \mathrm{AcONH4}(\mathrm{pH} \mathrm{3.6)}(5)$.

Next, the slides were incubated with an antibody directed against murine TNF- $\alpha$ (Alpha-Diagnostic International Inc., San Antonio, USA). Sections were counterstained with hematoxylin and eosin. TNF- $\alpha$ immunostaining was graded as follows: both nuclear and cytoplasmic staining 4; strong cytoplasm staining 3; moderate cytoplasmic staining 2 and slight cytoplasmic staining 1.

\section{Viral Titer in Heart}

The EMC viral titer in the individual hearts was determined in terms of the viral cytopathic effects, and is expressed as the tissue culture mean infectious dose (TCID50). The hearts on day 4 after the inoculation ( $n=3$ of each group) were homogenized in $2 \mathrm{ml}$ of MEM. After the centrifugation, the supernatants were added into 96-well microtiter plates containing human amnion cells in the MEM supplemented with $10 \%$ fetal calf serum as described previously (21). The microtiter plates were daily observed for 5 days to find the appearance of any cytopathic effects.

\section{Statistics}

Data are reported as means $\pm \mathrm{SD}$. The Kaplan-Meier curves were generated to analyse differences in survival. The differences in scores of myocardial damages were examined by two-way analysis of variance to reveal the combined effects of two different agents. Scheffes' $F$-test and Bonferroni/Dunn analysis were used for confirmation. A level of $P<0.05$ was considered statistically significant.

\section{Results}

\section{Prolonged Survival}

Survival rates on day 7 were $18.2 \%$ in group A, $18.2 \%$ in group B, $63.6 \%$ in group $\mathrm{C}$ and $23.3 \%$ in group $\mathrm{D}$. The survival rates on day 14 were $0 \%$ in group A, $0 \%$ in group $\mathrm{B}, 36.4 \%$ in group $\mathrm{C}$ and $0 \%$ in group $\mathrm{D}$. The survival rate in group $\mathrm{C}$ was significantly higher than those in groups A, B or $\mathrm{D}(P<0.05$, Fig. 2). Thus, treatment with Mao-to starting on the day 2 after EMC 


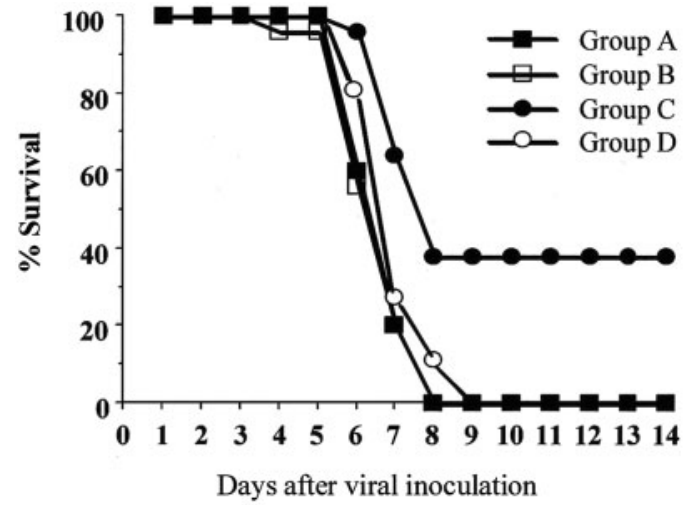

Figure 2. Survival in mice after viral inoculation. survival was significantly $(P<0.01)$ improved in the group $\mathrm{C}$ as compared with mice in groups A, B or D. Group A: administered with $0.1 \mathrm{ml}$ saline starting on day 0 to day 6 , group B: administered with $0.1 \mathrm{ml}$ Mao-to starting on day 0 to day 4, group $\mathrm{C}$ : administered with $0.1 \mathrm{ml}$ Mao-to starting on day 2 to day 6 , group $\mathrm{D}$ : administered $0.1 \mathrm{ml}$ Mao-to from day 5 to day 10 .

virus improved the survival, although Mao-to given earlier or later was not effective in this regard.

\section{Reduced Heart Weight}

The results are shown in Fig. 3. The BW in group A and $\mathrm{B}$ on day 6 after virus inoculation was significantly $(P<0.05)$ lower than that in group C. The HW/BW ratio in group $\mathrm{A}$ on day 4 was elevated compared with that of groups $\mathrm{B}$ and $\mathrm{C}(P<0.05)$. The HW and $\mathrm{HW} / \mathrm{BW}$ ratio in group $\mathrm{C}$ on day 6 after virus inoculation was significantly $(P<0.01)$ lower than that in group A. Additionally, the $\mathrm{HW} / \mathrm{BW}$ in group $\mathrm{C}$ on days 4 and 6 were significantly $(P<0.01)$ lower than those in group $\mathrm{B}$. However, the $\mathrm{HW}$ and $\mathrm{HW} / \mathrm{BW}$ ratio in group $\mathrm{C}$ on days 4, 6 and 14 did not differ significantly from those of the group N. In group D, HW and HW/BW ratio on day 6 were significantly higher than those in group $\mathrm{N}$.

\section{Decrease of Lung Congestion}

The lung weight $(\mathrm{LuW}) / \mathrm{BW}$ ratio on days 4 and 6 was increased in groups A and B compared with group $\mathrm{N}$. The LuW/BW ratio on days 4 and 6 were significantly reduced in group $\mathrm{B}$ and $\mathrm{C}$ vs. group $\mathrm{A}$. In group $\mathrm{C}$, the $\mathrm{LuW} / \mathrm{BW}$ ratio on day 4 was significantly lower than that in group $\mathrm{B}$, but that on day 6 was not significantly different than group $\mathrm{B}$. In group $\mathrm{D}, \mathrm{LuW} / \mathrm{BW}$ ratio on day 6 was significantly higher than that in group N.

\section{Reduction of Thymus Weight and Enlarged Spleen}

The thymus weight $(\mathrm{ThW}) / \mathrm{BW}$ ratio in groups $\mathrm{A}, \mathrm{B}, \mathrm{C}$ and $\mathrm{D}$ on day 6 was significantly $(P<0.05)$ lower than in the group $\mathrm{N}$ and the spleen weight $(\mathrm{SpW}) / \mathrm{BW}$ ratios in groups $\mathrm{A}, \mathrm{B}$ and $\mathrm{C}$ on days 4 and 6 were significantly $(P<0.05)$ higher than in group N (Fig. 4). Although the $\mathrm{ThW} / \mathrm{BW}$ ratio on day 6 in group $\mathrm{C}$ did not differ from that in group $\mathrm{A}$, the $\mathrm{SpW}$ in group $\mathrm{C}$ on day 6 was significantly $(P<0.05)$ higher than in groups $\mathrm{N}$ and $\mathrm{A}$. In group $\mathrm{D}$, ThW/BW ratio on day 6 was significantly lower than that in group $\mathrm{N}$ and $\mathrm{SpW} / \mathrm{BW}$ was significantly higher than that in group $\mathrm{N}$.

\section{Decreased Myocardial Diameter and Myocardial Damage}

The myocardial diameter was significantly smaller in group $\mathrm{C}$ than that in group $\mathrm{A}$ and $\mathrm{B}$ on day 6 , as shown in Fig. 5. Myofiber diameter in group A was significantly larger than that in group $\mathrm{N}$. The scores of myocardial necrosis and mononuclear cell infiltration were significantly reduced in group $\mathrm{C}$ compared with groups A, B and D on day 6 (Fig. 6A).

\section{Suppression of Expression of TNF- $\alpha$ in Heart}

Localized expression of TNF- $\alpha$ in the heart is shown in Fig. 6B. Endothelial cells and myofiber were positive for TNF- $\alpha$ in groups A and B on days 4 and 6. Myofibers from group $\mathrm{C}$ were less positive than those from groups $\mathrm{A}$ and $\mathrm{B}$ on day 6 . The grading of TNF- $\alpha$ immunostaining on day 6 was relatively lower in group $\mathrm{C}$ compared with those in group A, B or D $(P<0.05, n=3$ of each, Fig. 4). In addition, comparative expression of cardiac TNF- $\alpha$ mRNA in the group $C$ were significantly less than in the groups A, B or D (Fig. 7).

\section{Viral Titer in Heart}

On day 4, viral titer in the hearts was not significantly elevated in the Mao-to groups compared with that in the group A (group B; $3.3 \pm 0.8 \mathrm{TCID} / \mathrm{mg}$, group $\mathrm{C} ; 3.0 \pm 0.7$ $\mathrm{TCID} / \mathrm{mg}$ vs. group $\mathrm{A} ; 3.5 \pm 1.0 \mathrm{TCID} / \mathrm{mg}$ ), although the titer in group $\mathrm{C}$ was slightly lower than that in group A.

\section{Discussion}

At present, we have shown that Mao-to, administered 2 days after viral inoculation in $\mathrm{C} 3 \mathrm{H} / \mathrm{HeJ}$ mice, improves survival rates, and reduces both myocardial necrosis and mononuclear cell infiltration in mice with viral myocarditis. Accordingly, SpW/BW ratios were elevated in these mice. However, the administration of Mao-to at the same time as virus inoculation did not influence survival or myocardial destruction. We conclude that Mao-to has an anti-viral effect on EMC viral myocarditis in this mouse model in vivo and involves the modulation of early immune responses with the reduction of cardiac TNF- $\alpha$ 


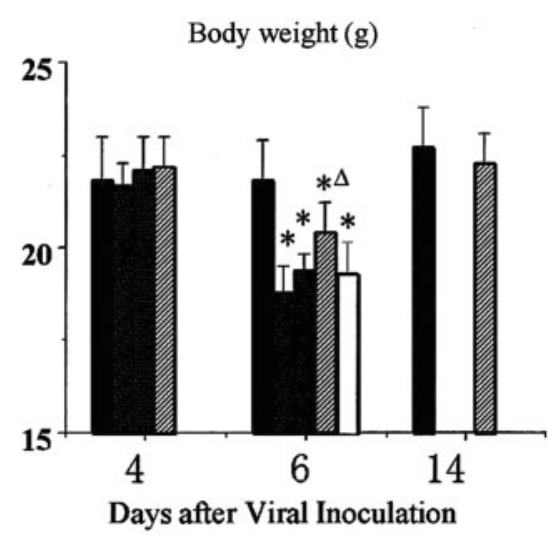

Heart weight/ Body weight ratio (x1000)

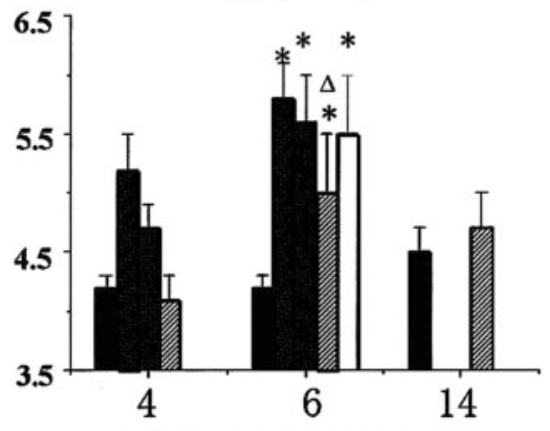

Days after Viral Inoculation

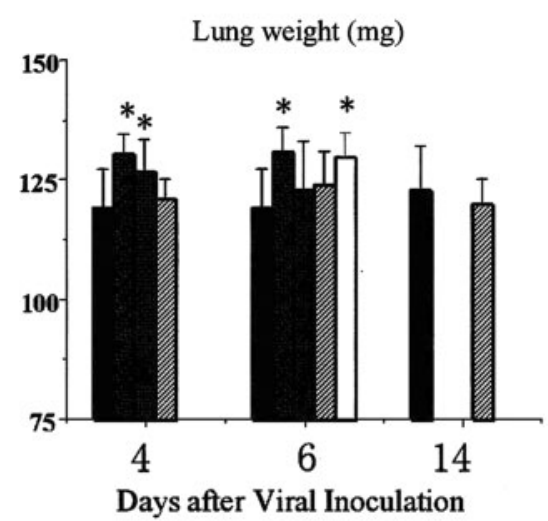

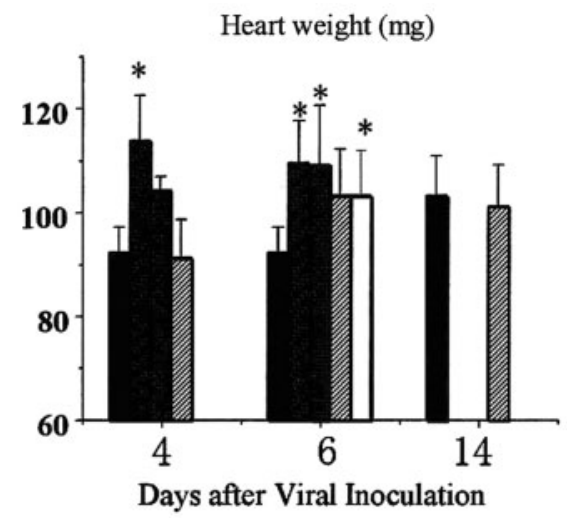

Group N
Group A
Group B
Group C
Group D

Lung weight / Body weight ratio $(\mathrm{x} 1000)$

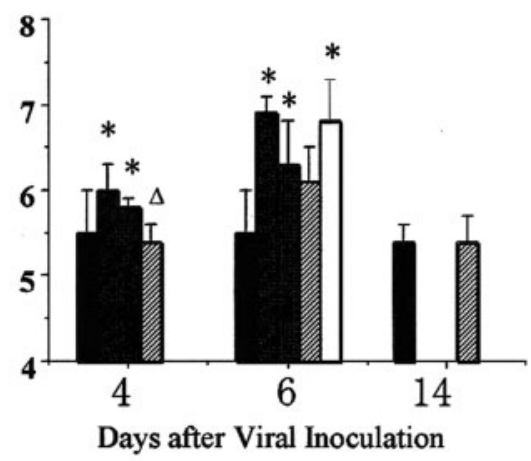

Figure 3. Heart and lung weight in murine viral myocarditis. Heart weight, heart weight/bodyweight ratio and lung weight/body weight ratio on day 6 was significantly reduced in group C compared with group N. Abbreviations; N: uninfected control mice, A: administered with $0.1 \mathrm{ml}$ saline starting on day 0 to day 6 , B: administered with $0.1 \mathrm{ml}$ Mao-to starting on day 0 to day 4, C: administered with $0.1 \mathrm{ml}$ Mao-to starting on day 2 to day 6. ${ }^{*} P<0.05$ vs. group $\mathrm{N}, \Delta P<0.05$ vs. group A.

mRNA, although the viral titer of hearts were not significantly changed.

The LuW/BW ratio reflects the degree of lung congestion. The two days later administration of Maoto and virus as group $\mathrm{C}$ leads to a significant reduction in $\mathrm{LuW} / \mathrm{BW}$ on day 6 . The reduction of $\mathrm{LuW} / \mathrm{BW}$ ratios in group B are considered to reflect an improvement in congestive heart failure due to viral myocarditis. The effect of Mao-to on histopathological changes depends on the timing of administration. As noted, when administered two days following viral inoculation, Maoto led to significant reduction of myocardial necrosis and mononuclear cell infiltration.

The reasons why oral administration of Mao-to was started on 2 days after virus inoculation, should be discussed. Our previous data showed that the both peaks of serum TNF- $\alpha$ and interferon were identified on day 2 after viral inoculation in this murine model (21). Neutralizing antibody titer was confirmed on day 4. Oral administration of Mao-to was effective in patients 
Thymus weight $(\mathrm{mg})$

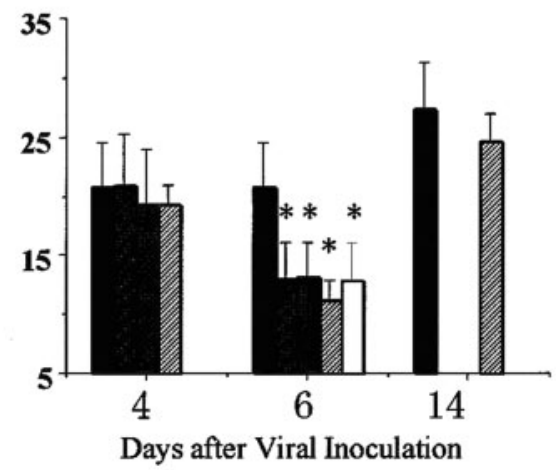

Spleen weight (mg)

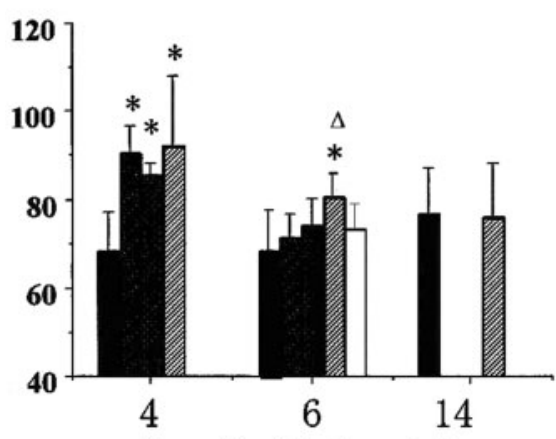

Days after Viral Inoculation
Thymus weight / B ody w eight ratio $(x 1000)$

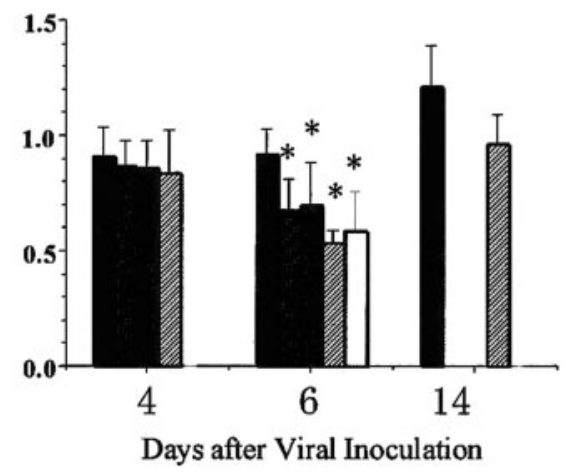

Spleen weight / Body weight ratio $(\mathrm{x} 1000)$

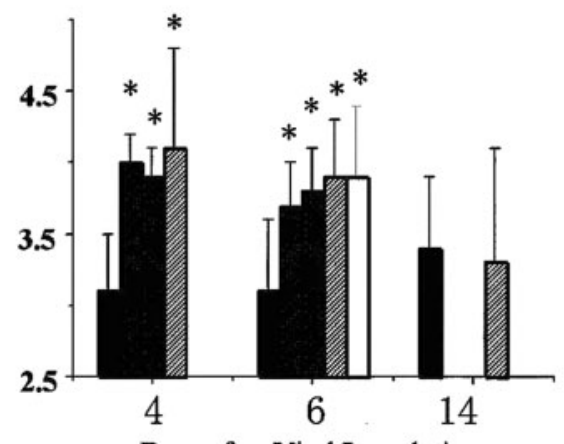

Days after Viral Inoculation

Figure 4. Thymus and spleen weight in murine viral myocarditis. Thymus weight in Mao-to-treated groups A, B, C and D were significantly reduced compared with group $\mathrm{N}$ on day 6 . Spleen weight/body weight ratio were significantly increased in group $\mathrm{C}$ compared with group $\mathrm{N}$. Groups as are described in Fig. $2 .{ }^{*} P<0.05$ vs. group $\mathrm{N}, \Delta P<0.05$ vs. group A.

already infected with influenza virus (10). Moreover, Mao-to has been reported to show an in vitro anti-viral effect (6). These reports suggest that the starting time of administration, 2 days after virus inoculation, could suppress these reactions instead of other days after virus inoculation.

The reasons why Mao-to administration starting on day 0 (group B) did not prolong the survival should be discussed. It is known that Mao-to increase the blood pressure, heart rate and cardiac output and decrease the total peripheral resistance (22). From day 0 to 4 , the main course of viral myocarditis is the infection of viral genome to myocytes, not the secondary immune cell infiltration in the heart. Mao-to administration on day 0 to 4 is possible to make myocyte damages worse by inducing excessive contraction of infected myocytes.

TNF- $\alpha$ is secreted primarily by myocytes and macrophages after injury (23). Elevation of TNF- $\alpha$ contributes to the extent of ventricular dysfunction as shown in TNF- $\alpha$ knockout mice (24). Previous studies have demonstrated that cardiac-specific expression of TNF- $\alpha$ results in myocardial inflammation, cardiac hypertrophy, progressive dilatation and increased apoptosis, which leads to heart failure and death (25). TNF- $\alpha$ may play an important role in modulating left ventricular dysfunction (26).

The present study also suggests that Mao-to may play a role in cytokine regulation of host defense mechanisms against viral myocarditis in mice in vivo. Comparative studies on anti-immune effects of Mao-to were reported. Mao-to prevents passive cutaneous anaphylaxis and also inhibits histamine and leukotriene $\mathrm{C} 4$ release from the mast cells (27). These suppressive effects may be due to the interaction of its components such as Ephedra Herba and Cassia Twig. The former was showed to suppress interleukin- 1 and 6 and the latter suppresses interleukin- $1 \alpha$ 


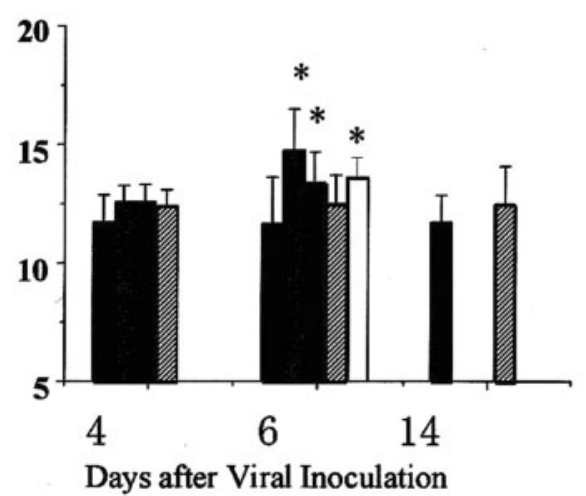

Mononuclear cell infiltration

( grade)

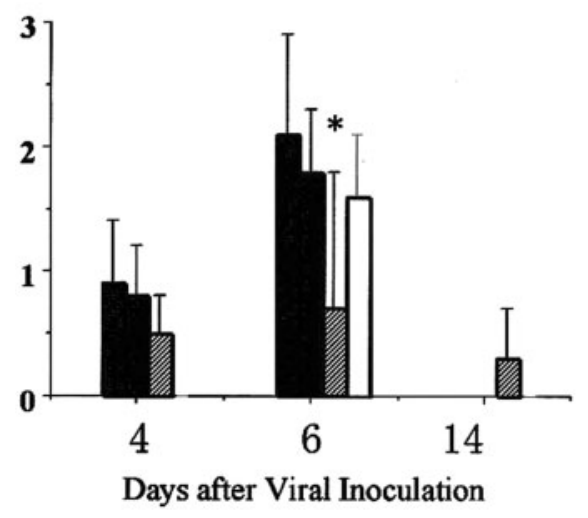

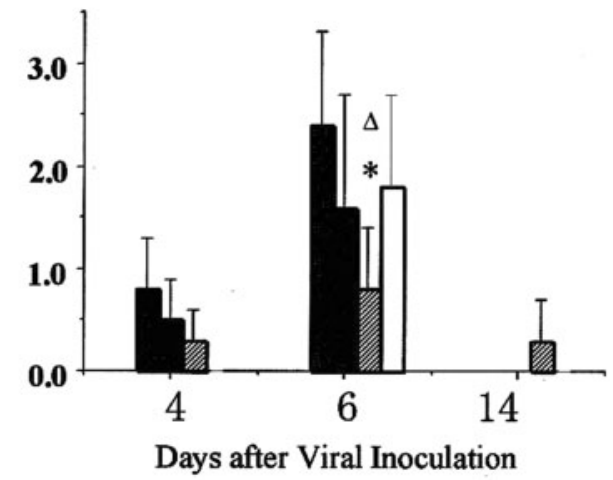

Comparative TNF- $\alpha$ expression

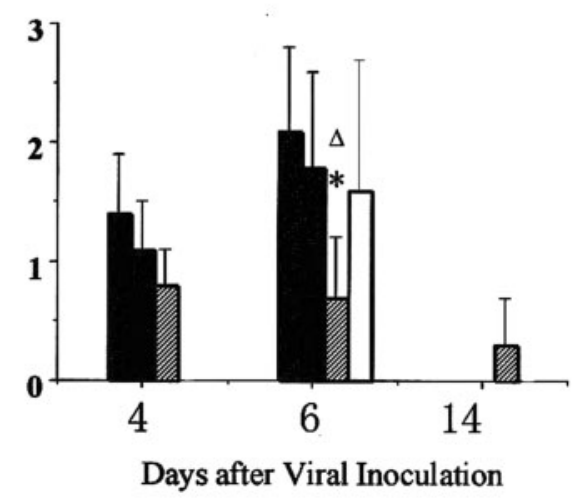

Figure 5. Myofiber diameter, cardiac histopathologic scores and grading of cardiac expression of TNF- $\alpha$ protein in murine viral myocarditis. Groups as are described in Fig. 2. Grades of severity of necrosis and mononuclear cell infiltration on a scale from 1 to 4 are as follows: grade 1, lesions involving $<25 \%$ of the ventricular myocardium; grade 2 , lesions involving $25-50 \%$ of the myocardium; grade 3 , lesions involving $50-75 \%$ of the myocardium; and grade 4 , lesions involving $75-100 \%$ of the myocardium. ND; not determined, ${ }^{*} P<0.05$ vs. group $\mathrm{N}, \Delta P<0.05$ vs. group A.

(6-8). The importance of neutralization in early anti-viral host defense is well appreciated. The anti-viral mechanism of Mao-to in mice may be to elicit these immune responses and to enhance immune cell function rather than to directly interfere with viral replication (10). Indeed, Mao-to was reported to be effective in the suppression of hepatitis virus in combination with interferon beta (6). Recently, Cinnamomi Cortex, a component of Mao-to, was reported to inhibit nuclear factor-kappa $\mathrm{B}(\mathrm{NF}-\kappa \mathrm{B})$ activation in mice (28). $\mathrm{NF}-\kappa \mathrm{B}$ is the most regulator of the innate immune response (29). Therefore, Mao-to might contribute to the regulation of innate immunity in vivo.

An additional reflection of immunomodulation by Mao-to was the enlargement of lymphoid organs, including spleen in group C. Although the precise mechanisms of Mao-to effect are not addressed by the examination of organ weights, the increased $\mathrm{SpW} / \mathrm{BW}$ and $\mathrm{ThW} / \mathrm{BW}$ ratios may be related to the immunomodulatory effect of Mao-to $(21,26)$.

In summary, oral administration of Mao-to two days after inoculation is beneficial to mice infected with the EMC virus and with subsequent active viral myocarditis. The present study supports the observations that Mao-to promotes temperately adaptive immune responses in spleen and heart muscle, and the consequent attenuation of viral replication when Mao-to is administered two days after the virus inoculation. However, Mao-to treatment must be concomitant with other treatment modalities. It would be better to further clarify the potential activities of Kampo medicine as well as Mao-to in basic investigations or clinical trials (30-32). Additional experiments are underway to explain specifically the mechanism by which Mao-to protects against viral myocarditis. 
A Hematoxy lin-eosin staining
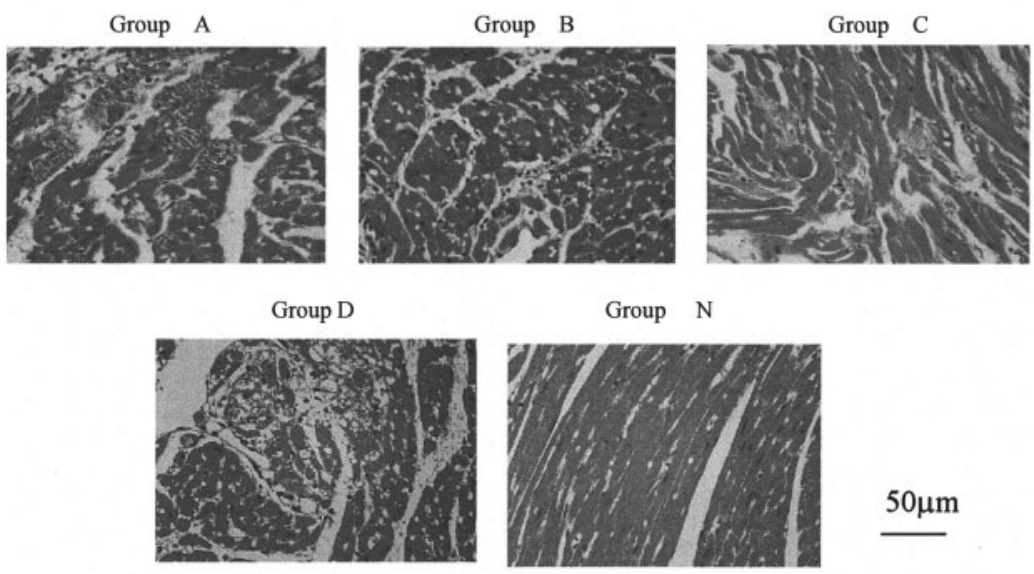

$50 \mu \mathrm{m}$

B TNF- $\alpha$ immunostaining
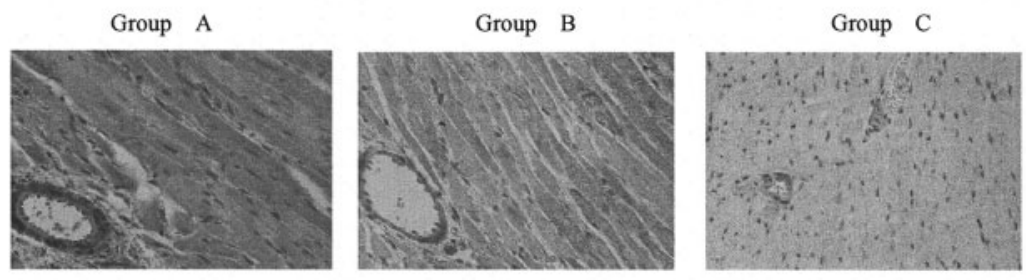

Group D

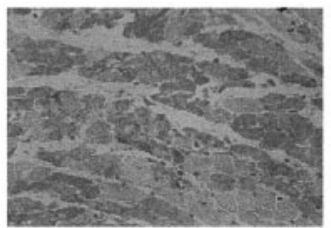

Group N

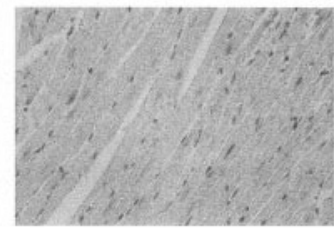

$50 \mu \mathrm{m}$

Figure 6. A. Pathologic findings of the heart in mice after viral inoculation. Myocardial necrosis and immune cell infiltration was observed on day 6. However, myocardial necrosis in group C on day 6 was reduced compared with the groups A, B and D. B. Immunohistochemical findings showed cardiac expression of TNF- $\alpha$ in the heart. Myofibers in the group C were less positive than in the groups A, B or D. Group A: administered with $0.1 \mathrm{ml}$ saline starting on day 0 to day 6 , group B: administered with $0.1 \mathrm{ml}$ Mao-to starting on day 0 to day 4 , group C: administered with $0.1 \mathrm{ml}$ Mao-to starting on day 2 to day 6, group D: administered $0.1 \mathrm{ml}$ Mao-to from day 5 to day 10 .

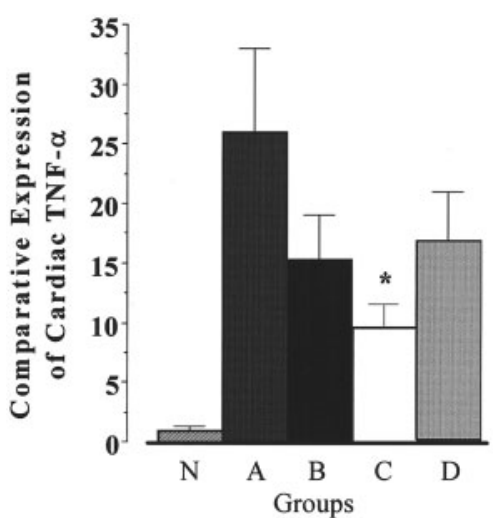

Figure 7. Comparative expression of cardiac TNF- $\alpha$ mRNA. This expression in the group $\mathrm{C}$ were significantly less than in the groups $\mathrm{A}, \mathrm{B}$ or D. Group A: administered with $0.1 \mathrm{ml}$ saline starting on day 0 to day 6, group B: administered with $0.1 \mathrm{ml}$ Mao-to starting on day 0 to day 4 , group C: administered with $0.1 \mathrm{ml}$ Mao-to starting on day 2 to day 6, group D: administered $0.1 \mathrm{ml} \mathrm{Mao-to} \mathrm{from} \mathrm{day} 5$ to day 10 .

\section{Acknowledgments}

This study was supported in part by a grant from the research fund of Institute of Kampo Medicine (Japan) (T. Takahashi, in 2006), a grant for Project Research from the High-Technology Center of Kanazawa Medical University (H2004-7), and a research grant from Grant-in-Aid for Scientific Research (C), the Ministry of Education, Science and Culture of Japan (T. Kanda, No. 17590767).

\section{References}

1. Caforio AL, Calabrese F, Angelini A, Tona F, Vinci A, Bottaro S, et al. A prospective study of biopsy-proven myocarditis: prognostic relevance of clinical and aetiopathogenetic features at diagnosis. Eur Heart $J$ 2007;28:1326-33.

2. Burian J, Buser P, Eriksson U. Myocarditis: the immunologist's view on pathogenesis and treatment. Swiss Med Wkly 2005;135:359-64.

3. Mason JW, O'Connell JB, Herskowitz A, Rose NR, McManus BM, Billingham ME, et al. A clinical trial of immunosuppressive therapy 
for myocarditis. The Myocarditis Treatment Trial Investigators. $N$ Engl J Med 1995;333:269-75.

4. Kuhl U, Pauschinger M, Schwimmbeck PL, Seeberg B, Lober C, Noutsias M, et al. Interferon-beta treatment eliminates cardiotropic viruses and improves left ventricular function in patients with myocardial persistence of viral genomes and left ventricular dysfunction. Circulation 2003;107:2793-8.

5. Kubo T, Nishimura H. Antipyretic effect of Mao-to, a Japanese herbal medicine, for treatment of type A influenza infection in children. Phytomedicine 2007;14:96-101.

6. Mantani N, Andoh T, Kawamata H, Terasawa K, Ochiai H. Inhibitory effect of Ephedra herba, an oriental traditional medicine, on the growth of influenza A/PR/8 virus in MDCK cells. Antivir Res 1999;44:193-200.

7. Tilg H, Trehu E, Atkins MB, Dinarello CA, Mier JW. Interleukin-6 as an anti-inflammatory cytokine: introduction of circulating IL-1 receptor antagonist and soluble tumor necrosis factor receptor. Blood 1994;83:113-8.

8. Kurokawa M, Kumeda CA, Yamamura J, Kamiyama T, Shiraki K. Antipyretic activity of cinnamyl derivatives and related compounds in influenza virus-infected mice. Eur J Pharmacol 1998;348:45-51.

9. Kainuma M, Ogata N, Kogure T, Kohta K, Hattori N, Mitsuma T, et al. The efficacy of a herbal medicine (Mao-to) in combination with intravenous natural interferon-beta for patients with chronic hepatitis C, genotype $1 \mathrm{~b}$ and high viral load: a pilot study. Phytomedicine 2002;9:365-72.

10. Kainuma M, Kogire T, Sekiya N, Mitsuma T, Shimada Y, Terawasa K. Changes of peripheral lymphocyte population in patients with chronic hepatitis $\mathrm{C}$ treated with herbal medicine (Maoto) and IFN- $\beta$. J Trad Med 2005;22:29-33.

11. Clark IA. How TNF was recognized as a key mechanism of disease. Cytokine Growth Factor Rev 2007;18:335-43.

12. Matsumori A, Yamada T, Suzuki H, Sasayama S. Increased circulating cytokines in patients with myocarditis and cardiomyopathy. Br Heart $J$ 1994;72:561-6.

13. Kanda T, Takahashi $\mathrm{T}$, Kudo $\mathrm{S}$, Takeda $\mathrm{T}$, Tsugawa $\mathrm{H}$, Takekoshi N. Leptin deficiency enhances myocardial necrosis and lethality in a murine model of viral myocarditis. Life Sci 2004;72:1435-47.

14. Sun M, Chen M, Dawood F, Zurawska U, Li JY, Parker T, et al. Tumor necrosis factor-alpha mediates cardiac remodeling and ventricular dysfunction after pressure overload state. Circulation 2007;115:1398-407.

15. Hegewisch S, Weh HJ, Hossfeld DK. TNF-alpha induced cardiomyopathy. Lancet 1990;2:294-5.

16. Kubota T, McTiernan CF, Frye CS, Slawson SE, Lemster BH, Koretsky AP, et al. Dilated cardiomyopathy in transgenic mice with cardiac-specific overexpression of tumor necrosis factor-alpha. Circ Res 1997;81:627-35.

17. Huber SA, Feldman AM, Sartini D. Coxsackievirus B3 induces T regulatory cells, which inhibit cardiomyopathy in tumor necrosis factor-alpha transgenic mice. Circ Res 2006;99:1109-16.
18. Hirasawa K, Kim A, Han H-S, Han J, Jun H-S, Yoon J-W. Effect of p38 mitogen-activated protein kinase on the replication of encephalomyocarditis virus. J Virol 2003;77:5649-56.

19. Kobayashi T, Song QH, Homg T, Kitamura H, Cyong JC. Antihyperglycemic effect of Mao-to a kampo formulation, in streptozotocin-induced diabetic mice. J Traditional Med 1999;16: $183-9$.

20. Hirasawa K, Jun HS, Maeda K, Kawaguchi Y, Itagaki S, Mikami $\mathrm{T}$, et al. Possible role of macrophage-derived soluble mediators in the pathogenesis of encephalomyocarditis virusinduced diabetes in mice. J Virol 1997;71:4024-31.

21. Kanda T, McManus JE, Yang DC, McManus BM, Imai S, Suzuki T, et al. Modification of viral myocarditis in mice by interleukin-6. Circ Res 1996;78:848-58.

22. Xu FH, Uebaba K. Effect of Kampo formulations (traditional Chinese medicine) on circulatory parameters. Acupunct Electrother Res 1999;24:11-28.

23. Kapadia SR, Oral H, Lee J, Nakano M, Taffet G.E, Mann DL. Hemodynamic regulation of tumor necrosis factor-alpha gene and protein expression in adult feline myocardium. Circ Res 1997:81:187-95.

24. Sun M, Dawood F, Wen WH, Chen M, Dixon I, Kirshenbaum LA, et al. Excessive tumor necrosis factor activation after infarction contributes to susceptibility of myocardial rupture and left ventricular dysfunction. Circulation 2004;110:3221-8.

25. Myrianthefs PM, Lazaris N, Venetsanou K, Smigadis N, Karabatsos E, Anastasiou-Nana MI, et al. Immune status evaluation of patients with chronic heart failure. Cytokine 2007;37:150-4.

26. Yokoyama T, Vaca L, Rossen RD, Durante W, Hazarika P, Mann DL. Cellular basis for the negative inotropic effects of tumor necrosis factor-alpha in the adult mammalian heart. J Clin Invest 1993;92:2303-12.

27. Nynt AK, Takeuchi Y, Yokomuro K, Miyanaga Y. Comparative studies on antiallergic effects of kampo medicines used for the therapy of respiratory diseases. Jpn J Allergol 1995;44:503-12.

28. Kwon KB, Kim EK, Jeong ES, Lee YH, Lee YR, Park JW, et al. Cortex cinnamoni extract prevents streptozotocin-, \& cytokineinduced beta-cell damage by inhibiting NF-kappaB. World $J$ Gastroenterol 2006;12:4331-7.

29. Carmody RJ, Chen YH. Nuclear factor-kappaB: activation and regulation during toll-like receptor signaling. Cell Mol Immunol 2007;4:31-41.

30. Terasawa K. Evidence-based reconstruction of Kampo medicine: part I-is Kampo CAM? Evid Based Complement Alternat Med 2004:1:11-6.

31. Terasawa K. Evidence-based reconstruction of Kampo medicine: part II-the concept of Sho. Evid Based Complement Alternat Med 2004;1:119-23.

32. Terasawa K. Evidence-based reconstruction of Kampo medicine: part-III-how should Kampo be evaluated? Evid Based Complement Alternat Med 2004;1:219-22.

Received February 15, 2007; accepted January 14, 2008 


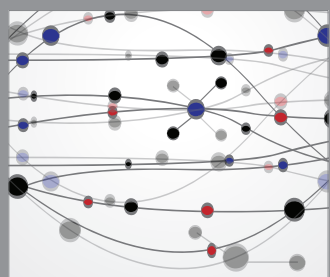

The Scientific World Journal
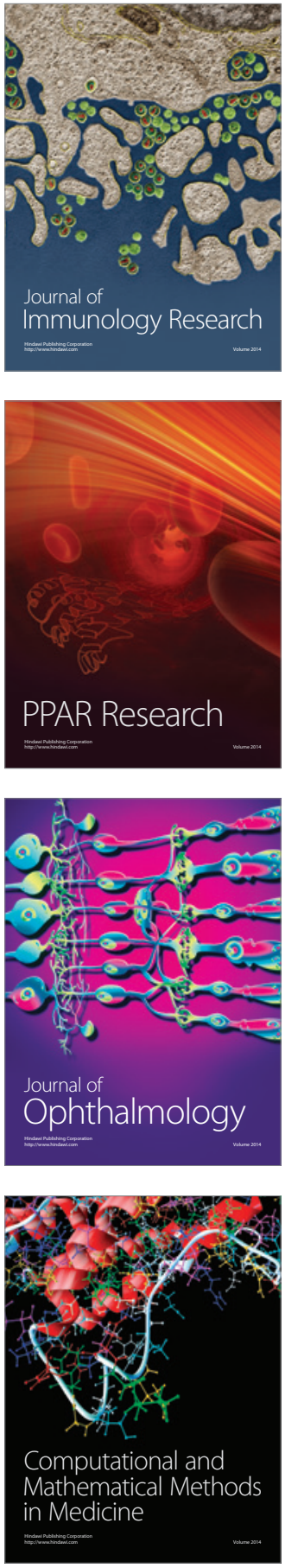

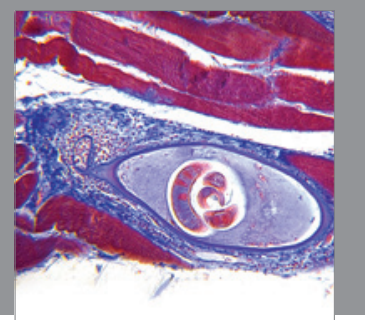

Gastroenterology

Research and Practice
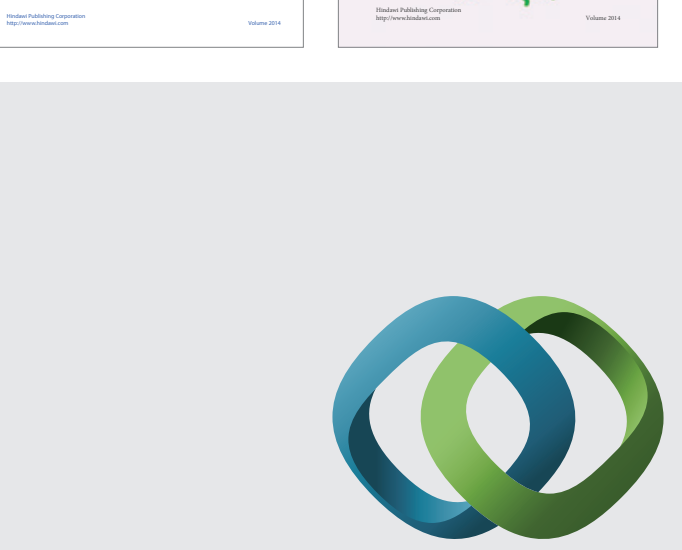

\section{Hindawi}

Submit your manuscripts at

http://www.hindawi.com
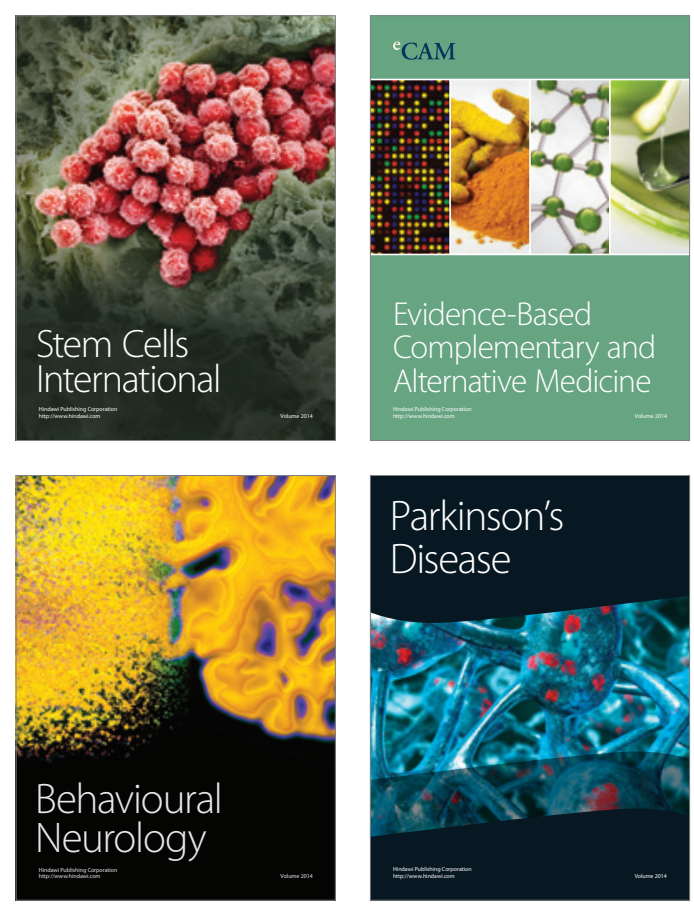

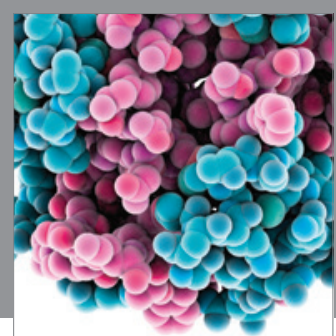

Journal of
Diabetes Research

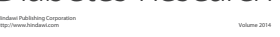

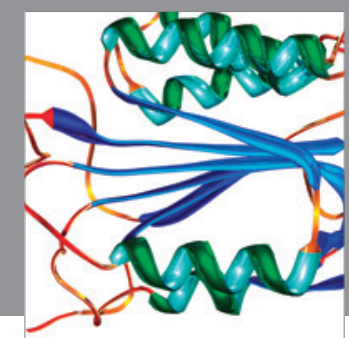

Disease Markers
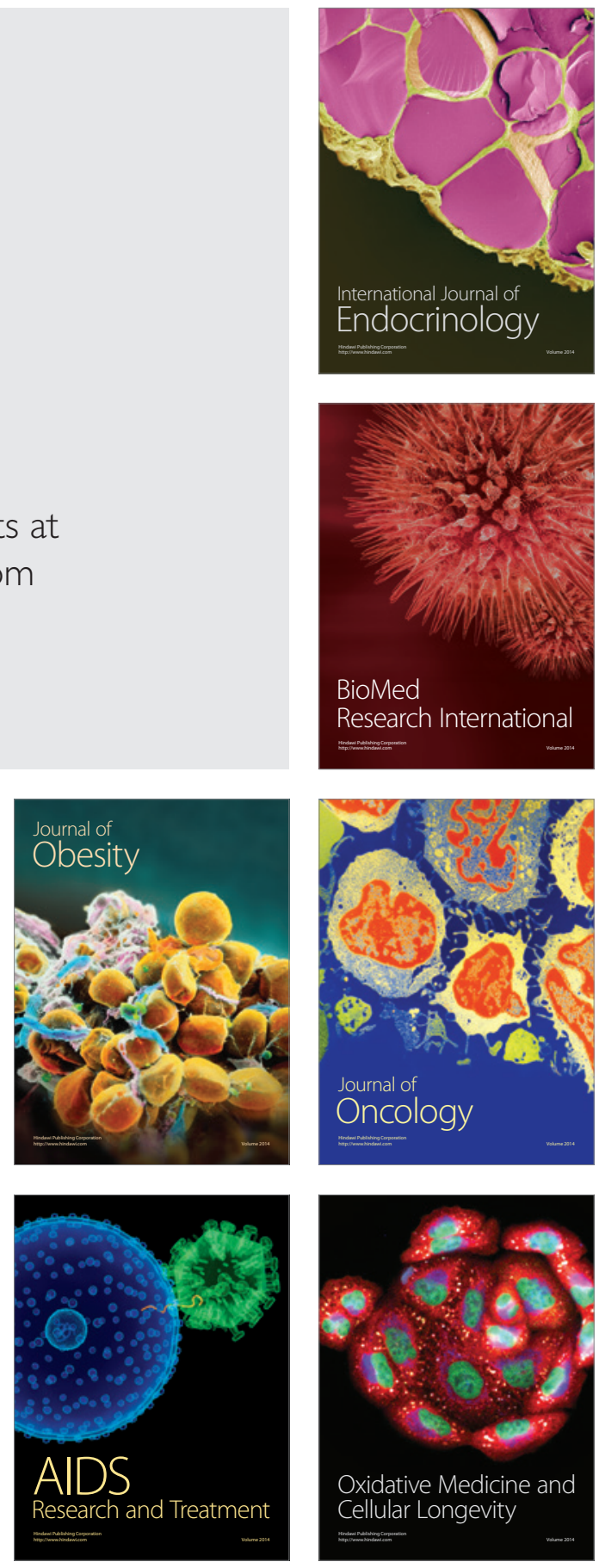